\title{
Correction to: Intra-cluster correlation coefficients in primary care patients with type 2 diabetes and hypertension
}

\author{
Yi Lin Lee ${ }^{1 *}$, Yvonne Mei Fong Lim², Kian Boon Law ${ }^{1}$ and Sheamini Sivasampu
}

\section{Correction to: Trials 21, 530 (2020). \\ https://doi.org/10.1186/s13063-020-04349-4}

Following publication of the original article [1], we were notified of a typographical error in the Method section, page 2, paragraph 4 .

The first sentence is incomplete. It should read: "There were four phases of data collection for 31 time points (in months): (1) November 2016 to June 2017 (pre-intervention), (2) August 2017 to June 2019 (post-intervention)." The original article has been corrected.

\section{Author details}

${ }^{1}$ Centre for Clinical Trial, Institute for Clinical Research, Ampang Hospital, Ministry of Health, Jalan Mewah Utara, Pandan Mewah, 68000 Ampang, Selangor, Malaysia. ${ }^{2}$ Centre for Clinical Outcome Research, Institute for Clinical Research, National Institute of Health, Ministry of Health, Kompleks Institut Kesihatan Negara (NIH), No. 1, Jalan Setia Murni U13/52, Seksyen U13, Setia Alam, 40170 Shah Alam, Selangor, Malaysia.

Published online: 10 September 2020

\section{Reference}

1. Lee $Y L$, et al. Intra-cluster correlation coefficients in primary care patients with type 2 diabetes and hypertension. Trials. 2020;21:530. https://doi.org/ 10.1186/s13063-020-04349-4.

\footnotetext{
The original article can be found online at https://doi.org/10.1186/s13063020-04349-4

* Correspondence: yl.yilinlee@gmail.com

${ }^{1}$ Centre for Clinical Trial, Institute for Clinical Research, Ampang Hospital,

Ministry of Health, Jalan Mewah Utara, Pandan Mewah, 68000 Ampang, Selangor, Malaysia

Full list of author information is available at the end of the article
}

(C) The Author(s). 2020 Open Access This article is licensed under a Creative Commons Attribution 4.0 International License, which permits use, sharing, adaptation, distribution and reproduction in any medium or format, as long as you give appropriate credit to the original author(s) and the source, provide a link to the Creative Commons licence, and indicate if changes were made. The images or other third party material in this article are included in the article's Creative Commons. licence, unless indicated otherwise in a credit line to the material. If material is not included in the article's Creative Commons licence and your intended use is not permitted by statutory regulation or exceeds the permitted use, you will need to obtain permission directly from the copyright holder. To view a copy of this licence, visit http://creativecommons.org/licenses/by/4.0/ The Creative Commons Public Domain Dedication waiver (http://creativecommons.org/publicdomain/zero/1.0/) applies to the data made available in this article, unless otherwise stated in a credit line to the data. 